\title{
The paradox of public participation in fisheries governance. The rising number of actors and the devolution process
}

${ }^{a}$ Department of Human Geography, University of Seville, Maria de Padilla, s/n, 41004 Seville, Spain

${ }^{\mathrm{b}}$ Department of Social Anthropology, University of Seville, Maria de Padilla, s/n, 41004 Seville, Spain

During the process by which the number of actors was increased manifold as a result of the development of civil society, the fisher community has lost prominence and importance, fading into the wide spectrum of interests with which it is competing to make its voice heard in decision-making bodies and in the media. This results in what could be termed the participation paradox - the greater the number of actors, the smaller the role each plays, and the lesser the importance of traditional sectors. Participation and devolution do not bear a linear relationship; greater devolution does not necessarily result in greater participation, a claim that has contributed to the processes of devolution being overvalued. Governance, as interaction between State, civil society and the market, paradoxically might not strengthen the most traditional of the interest groups.

(C) 2007 Published by Elsevier Ltd.

Keywords: Fisheries governance; Participation; Devolution; Co-management; Stakeholders; Competition.

\section{Introduction}

Recent developments (from around the beginning of the 1990s onwards) in studies on fisheries management have revolved around the ideas of decentralization, devolution, regionalization and participation. ${ }^{1}$ The crisis in the fishing industry in developed economies and in European Union member countries in particular, has led to the management systems themselves being questioned [1] as being incapable of bringing a halt to the decrease in resources. This has, in turn, resulted in the decline both of areas dependent on fishing and of fisher communities that are ever more reticent about the CFP. In short, twin crises that have both biological and institutional aspects.

A series of research studies conducted as part of the various EU Framework Programmes have in recent years explored possible alternatives to the management systems

\footnotetext{
${ }^{*}$ Corresponding author. Tel.: + 34954551365 ; fax: +34954556988 .

E-mail address: vivero@us.es (J.L. Suárez de Vivero).

${ }^{1}$ A superficial examination of the literature on this matter published in Marine Policy during the period 1989-2006 shows that the interest of social scientists has been focused on these topics.
}

that predominate in European institutions [2,3] with a single common denominator-to strengthen the participation of the whole gamut of social actors in order that reforms, characterized by the hefty reduction in the fishing effort, might be taken on board and the EU fishing policy thus given greater legitimacy and credibility. One working hypothesis that has been accepted is excessive centralism on the part of the Commission, the disadvantage of which is the distancing of those it is administrating. Consequently, the need to begin a process of devolution that might allow the traditional actors in the fishing industry to regain a lead role is being looked at. ${ }^{2}$ A plethora of concepts relating to devolution and participation have been considered with the aim of establishing new regulatory frameworks for fisheries management and the relationship between the industry and the institutions.

This paper assumes the following premises: (i) During the process by which the number of actors was increased manifold as a result of the development of civil society, the fisher, the fisher community, has lost prominence and

\footnotetext{
${ }^{2}$ For the Commission's determination and political will in carrying through this devolution process, see [4].
} 
1 importance, fading into the wide spectrum of interests with which it is competing to make its voice heard in decisionmaking bodies and in the media. This results in what could be termed the participation paradox - the greater the number of actors, the smaller the role each plays, and the lesser the importance of traditional sectors. (ii) Participation and devolution, in a variety of expressions, such as regionalization and decentralization, do not bear a linear relationship; greater devolution does not necessarily result in greater participation, a claim that has contributed to the processes of devolution being overvalued. (iii) The notions of devolution, participation and co-management, which at the turn of the century have been milestones in the process of perfecting fisheries management, what is now also a more complex process, however, have been included in the governance paradigm. Governance, as interaction between State, civil society and the market, paradoxically might not strengthen the most traditional of the interest groups.

The analysis herein is structured into three main ideas: (i) decentralization and participation, (ii) co-management, and (iii) governance and governability, in which it is possible to include the main contributions made by social sciences to fisheries management in recent years.

\section{Devolution: interpretive scheme}

The way democracy has developed and the deeper roots that it has put down over recent decades are closely linked with the process of building what is known as civil society. Representative democracy concentrated decision-making in large institutions limiting citizen participation to the election of representatives in State bodies. Professional and guild organizations which in activities like fishing had played a highly relevant role in management until well into the 20th century [5] lost the influence they used to bear to State institutions (including scientific institutions) to the point that in some European countries, the latter have reached the stage where they monopolize the function of fisheries management [6]. Nevertheless, over the last 20 years there has been an evident trend towards a demand for the participation of individuals, interest groups and associations in public affairs through the debate about participatory democracy or direct democracy. The latest currents in social sciences highlight the importance of participation in social movements and in voluntary action networks as one of the elements that develops the capacity of individuals to assume self-government. ${ }^{3}$

This new track towards management models with greater participation has led not only to a resurgence of traditional organizations in Europe (in Spain, the Fishermen's Guilds), but also the creation of new ones, such as producer organizations, although with patchy results. Given this set of circumstances, proposals aimed at reducing the role played by the State in favor of either

\footnotetext{
${ }^{3}$ Self-government means the freedom to govern through the absence of
} control. the various actors in civil society or of the market, have been transferred to the sphere of the fishing industry in such a way that a range of concepts such as regionalization, decentralization, delegation, subsidiarity, co-management, sharing responsibilities, self-management, empowerment and deconcentration, have been used in the design of alternative management models.

All these concepts can be included in an interpretive scheme which relates the degree of participation to the degree of centralization-decentralization. In the case of Spain $^{4}$ (Fig. 1), this allows the different expressions to be seen as the process develops whilst also offering an overview of their relative positions on the Participation-Decentralization axis and on the path that runs between the centralized State model (pre-1978) and a theoretical State which combines the highest level of participation with the greatest degree of decentralization. These expressions of the devolution process relate to the general management of fisheries activity (in which the various tiers of administration are involved) as well as to sub-sector forms of fishing that in an experimental or circumstantial way have included initiatives with a greater involvement on the part of fishers and other agents in the fisheries chain.

It is evident by the way in which fisheries management has evolved in the various European countries that progress from greater decentralization to greater selfgovernment is not necessarily made in a straight line, and the example of the European Union, where the CFP involves the loss or transfer of State sovereignty to EU institutions, corroborates this. In a similar fashion, the different options for particular types of devolution do not require a progressive, step-by-step course towards greater decentralization or regionalization. ${ }^{5}$ In other regards, as can be seen from the cases of Spain, France, Norway, Denmark and the United Kingdom, ${ }^{6}$ it is possible for a high level of political and administrative decentralization to coexist with a limited degree of participation on the part of social agents and, in sensu contrario, likewise centralized State models with a highly developed culture of participation. Participation as an expression of politically advanced societies can, to an extent, be understood as an independent variable of the State organizational model but always, naturally, in the context of the modern democratic State with direct representation (Fig. 2).

\footnotetext{
${ }^{4}$ Spain is peculiar in the sense that it has undergone a radical reform in the way the State is politically and territorially organized (the 1978 Constitution), going from being a centralized structure to a highly decentralized one (Autonomous Communities) almost akin to a federal State.

${ }^{5}$ The possibility of moving from centralized management to comanagement is shown in [7].

${ }^{6}$ The European Sharing Responsibilities in Fisheries Management [8] project proposes and assesses alternative fisheries management models with a greater degree of decentralization with regard to EU and State administrations, and greater participation by the various stakeholders.
} 


\section{ARTICLE IN PRESS}

J.L. Suárez de Vivero et al. / Marine Policy

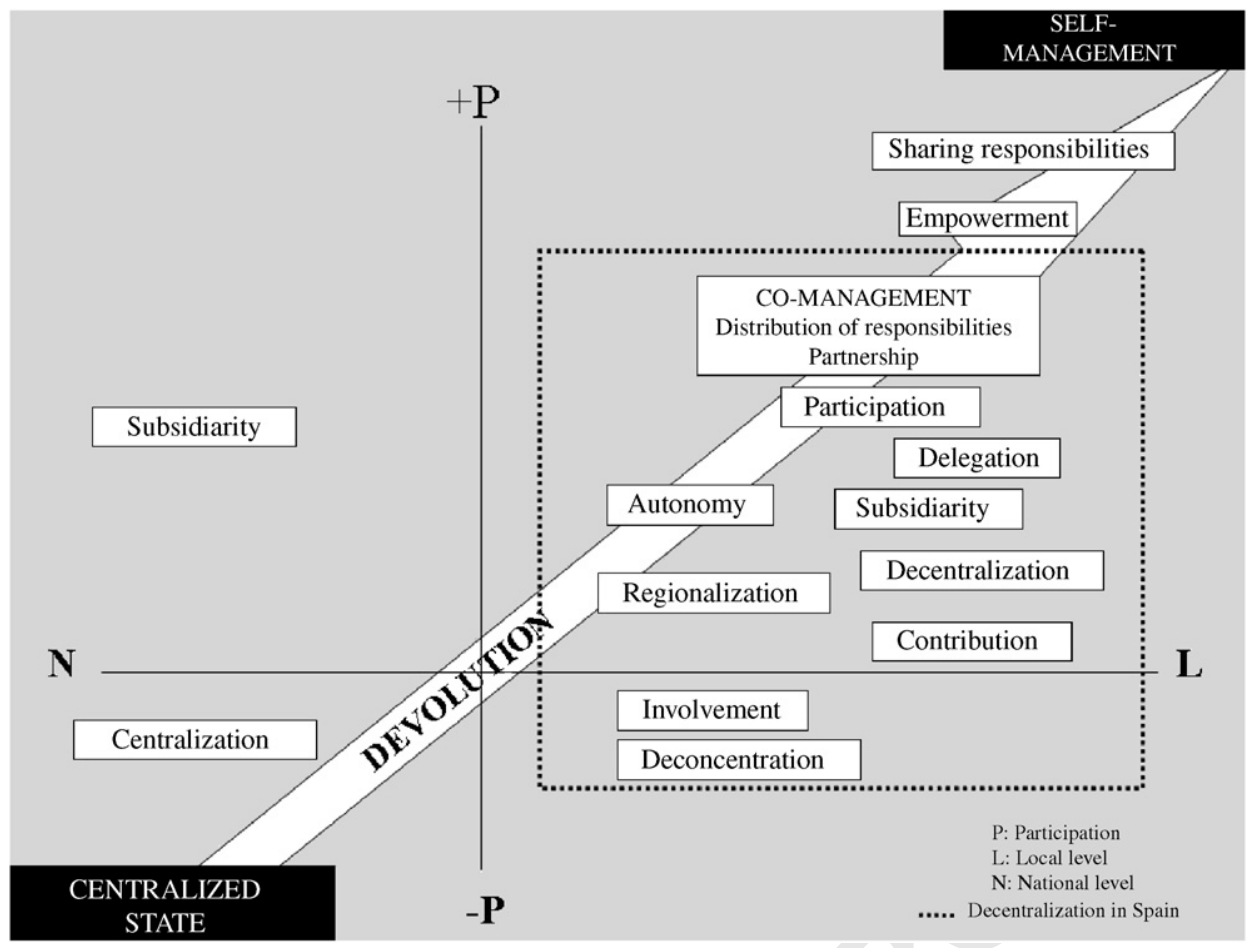

Fig. 1. Ratio between participation and decentralization. The situation in Spain.

\section{Co-management}

Co-management is without doubt a key concept in the recent development of theory and praxis in fisheries management. Firstly, because other concepts that are relevant to the scientific discussion on fisheries manage-

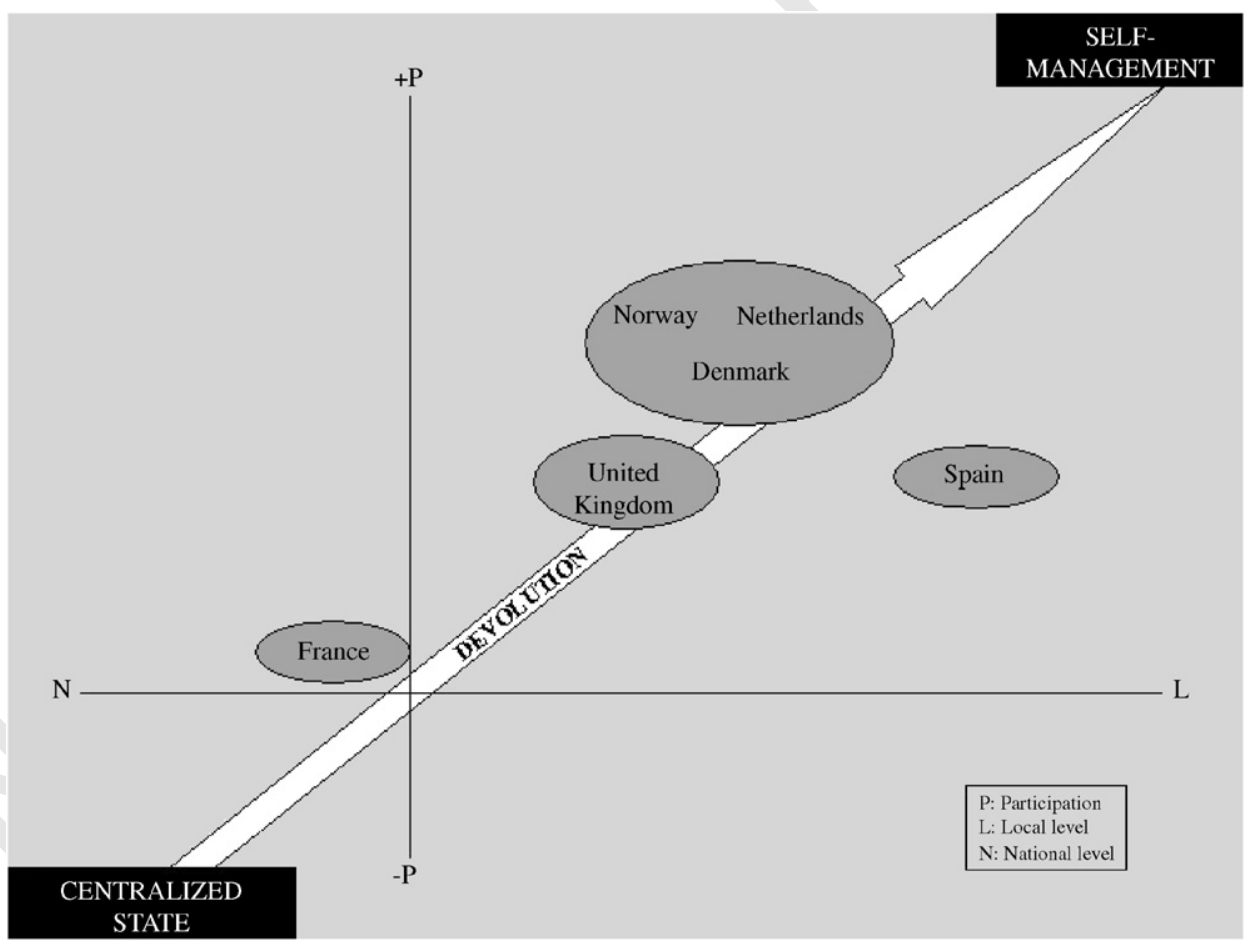

Fig. 2. Ratio between participation and decentralization in some European countries.
61

63

65

67

69

71

73

75

77

79

81

83

85

87

89

91

93

95

97

99

101

103

105

107

109 other more technical and limited terms, such as participatory/collaborative/cooperative management and community based management [9]. And, secondly, because the way the concept itself has evolved from the 1980s to the present day is an indication of the direction of the prevalent points of 
1 view in scientific discourse regarding fisheries management - an advance towards participation by new social agents and the progressive decentralization of the decisionmaking processes [10]. There are three key elements to this concept, which was developed by specialist literature during the 1990s: (i) the need for decentralization given the failure of the centralist system dominated by the State as a political agent which went before, (ii) the importance of social agents' participation in the political process, and (iii) the recognition of folk management systems [11]. These three features should better guarantee the fishers' confidence in the political system, which, according to comanagement paradigm theorists, would then result in measures being better applied.

It is a fact that the intense use of the term has led to greater ambiguity, whereby it has become a label for a broad gamut of proposals, both as regards objectives and the social agents and institutions involved in the process. Because of this, several papers have made great efforts to define the term theoretically [12] and to classify different types of co-management $[13,14]$. If we take as our base reference the definition offered by Jentoft in 1989 [15,16], co-management is understood as some kind of partnership between the administration and the associations that represent the fishers for sharing responsibility for management tasks, and it is specifically this that distinguishes it from consultative arrangements. The need to augment the political effectiveness and legitimacy of traditional top-down management systems, especially through an increase in the compliance of the fishers, was the prime argument of the proposal, and this is how it has persistently been seized upon in subsequent tradition.

But innovative elements are nonetheless important in scientific discourse. The most important of these has been the opening up of the co-decision political process to new social and institutional subjects, to the point that the idea of partnership between fishers and the administration has been quite clearly surpassed. As such, in the second half of the 1990s [13,17], co-management was understood as the result not just of collaboration between users groups (with these no longer being explicitly limited to the fishers) and the government, but also agencies and research institutions. From this moment on, the concept broadens, especially with regard to who ought to form part of the system. This option is clearly defined in Mikalsen and Jentoft [18] fisheries management should involve new social agents through more inclusive and participatory methodology that transcends sectoral limits. It should take as its basis the stakeholder approach; that is, it should take into consideration all the social and institutional agents that have a legitimate right to be consulted in fisheries policy decisions in recognition of the fact that fish stocks and maritime territory are a common property resource; to wit: local communities, environmental organizations and agencies, researchers, consumers, the media, representatives of the fisheries chain and other maritime industries, and future generations. The focus also establishes that the system of relationships between these subjects should remain under State control, with the State being primarily understood to be an arbiter in a complex assemblage rather than one of the cornerstones of the system occupying a hierarchical position.

Having come thus far, it seems evident that the concept of co-management should be associated with: (a) the strengthening of the local perspective, in the sense that the community should be restored as a key domain in management $[19,20]$; (b) the delegation of power from governmental agencies to social and institutional agencies linked to the fisheries chain and local communities; that is, it should be associated with the empowerment of these very agents [21]; (c) more inclusive and transparent institutions, more democratic instruments; and (d) a political system which steers clear of the cognitive exclusiveness of science and incorporates forms of "folk" knowledge; and all the aspects that this entails [22,23].

All the potentialities of co-management having been set out, it is now necessary to point out the difficulties that exist for it to be implemented: (a) the need to work on a variety of political and territorial scales; (b) adaptation to the wide variety of social agents' needs; (c) the reluctance of

\begin{tabular}{|l|l|}
\hline Traditional Management Model & Governance Model \\
\hline Technical tool (management) & Global, holistic perspective (governance) \\
\hline $\begin{array}{l}\text { Based on "closed" knowledge (bio- } \\
\text { economic science) }\end{array}$ & $\begin{array}{l}\text { Based on "open" knowledge (the interaction } \\
\text { between science and social or folk knowledge) }\end{array}$ \\
\hline Top-down & Multi-level (from global to local level) \\
\hline $\begin{array}{l}\text { Pre-established values (economic } \\
\text { efficiency, technological } \\
\text { development, etc.) }\end{array}$ & $\begin{array}{l}\text { Values under construction (social and } \\
\text { environmental sustainability; cultural diversity; } \\
\text { political effectiveness; democracy) }\end{array}$ \\
\hline $\begin{array}{l}\text { Static power relationships (State, } \\
\text { associations, market lobbies). }\end{array}$ & $\begin{array}{l}\text { Dynamic power relationships (devolution,co- } \\
\text { participation, accountability, policy networks, } \\
\text { etc.) }\end{array}$ \\
$\begin{array}{l}\text { Traditional actors (government } \\
\text { agencies, fishers) }\end{array}$ & $\begin{array}{l}\text { New actors (citizen, environmental, mass media, } \\
\text { and non-extractive fishery sector representative } \\
\text { organizations) }\end{array}$ \\
\hline $\begin{array}{l}\text { Bioeconomic paradigme } \\
\text { (Maximum sustainable yield) }\end{array}$ & $\begin{array}{l}\text { Integrative approach } \\
\text { (Ecosystem base approach) }\end{array}$ \\
\hline
\end{tabular}

Fig. 3. Comparison between traditional management model and governance model. 
1 the State to delegate a share of power and especially to becoming sensitized to local/regional conditions (given its centralizing vocation); (d) the status quo of the power relationships in the fisheries chain at the current time, with historical control by the marketing and industrialization agents growing due to the processes of globalization; (e) the representativeness of the fisheries organizations and their lack of political coordination; (f) the lack of prior experiences after a long period of time with a centralized management model; and $(\mathrm{g})$ the very ambiguity of the concept, under which a wide range of experiences are presented. Bearing in mind all these difficulties, it might be conjectured that the failures of premature and insufficiently robust co-management experiences put the potential existence of the focus at risk. Be that as it may, the theoretical development of the concept towards a permanent opening up to social agents as participants in the decision-making process allows us to accept what we have referred to as the participation paradox. The truth of the matter is fishers have progressively lost their decisionmaking capacity and political presence as they have had to compete with the viewpoints, objectives and strategies of other actors who have recently been invited to take a political part. (Fig. 3).

\section{Governance and governability}

Governance and governability represent a third important milestone in this discourse on the role of social participation in fisheries management as they bring together in one way or another these devolution and comanagement concepts and approaches. In simple terms, the governance/governability paradigm equates to a large "melting-pot-concept" into which are poured all the preceding approaches to fisheries management and the principles that inspire them: participation, decentralization and flexibility.

Governance is on occasion interpreted as an action executed by the government (when this is understood to be a grouping of formal executive power institutions), although it is much more than this. ${ }^{7}$ Kooiman [25] defined it as the free play of participation and trade-off between the various social actors, and between the public and private sectors, without traditional government intervention, "coordination without a coordinator" or a type of "governing without Government" [26,27]. Governance could therefore be defined as a kind of social coordination (as opposed to coordination based on the market or based on politics) that is born out of the constant interaction between social agents of all types. The concept is associated with the capacity for self-coordination that networks made up of a

\footnotetext{
${ }^{7}$ For example, one of the things that Stoker [24] puts forward is the idea that governance could develop not only from formal institutions, but also from others. He also asserts that there is an interdependence between the various actors in this model and that self-organized networks of social actors progressively gain importance.
}

wide variety of public and private, State and transnational organizations and bodies possess [28].

From the 1990s onwards, and especially after 2000, the concept of governance burst onto the ocean and fisheries management scene, ${ }^{8}$ in an attempt to provide an explanation to a dynamic, complex, ever-changing, often crossborder reality in which social and institutional groups (State, market, civil society) with generally diverse interests interact. The concept of governance seems to be more related to the need to manage a complex socio-economic and physical reality and to the achievement of certain goals that characterize the post-modern era [32].

Development grown out of traditional systems of fisheries management, in which the State was key, and where some social actors (fishers, basically) were sometimes taken into consideration, has more recently turned into more flexible management, with a more prominent role played by the market and its resource assignation mechanisms. Ocean and fisheries governance is, after all, founded on an already very robust epistemological product and on a series of key principles (sustainability, participation, transparency, accountability, flexibility and precaution, to name but some ${ }^{9}$ ) that have afforded it a measure of prestige in the scientific community and that provide adequate guidelines for analysis (the descriptive aspect) and intervention (the prescriptive aspect). Of all the different types of governance - hierarchical governance (based on administrative rationality), market governance (based on economic rationality) and participatory governance (founded on social consensus and "democratic pragmatism")- it is the third and last of these that would seem to be prevailing today, with its post-materialistic foundations, the value of responses based on collective knowledge and action, the need for decentralization and the loss of steam of the other two models [37].

Governability is a different concept, but one which complements governance. It refers to issues such as order, stability, efficiency and the legitimacy of a management system; that is, the effectiveness with which the range of socio-political actors arrive at decisions and the capacity of institutions and government to apply and implement them. In short, governability would be a capacity or an attribute for governing (associated with some public power or a political system), whereas governance refers above all to the structures (game rules) and processes which condition the participation and interaction of the various sociopolitical actors [38]. Governability comprises both the political system of management (governance) and the

\footnotetext{
${ }^{8}$ From a quick review of references on intervention policies and mechanisms in the ocean environment, it can be seen that articles and books written during the 1970s and 1980s bear names that preferentially include the concepts of marine policy or ocean management, whereas from the 1990s onwards the concept of ocean governance predominates in titles [29-31].

${ }^{9}$ These principles can be looked up in a number of documents and articles [33-36].
} 
1 socio-economic reality that is to be managed, as well as interaction between both.

At the current time, fishing is both affected and structured by three institutional orders (State, community, market), and there has been a notable retreat of State institutions and the lack of adaptation of their structures to the reality of the market and ecology whilst at the same time there has also been an increase in the number of market solutions (a quest for efficiency, ITQs and so on) [6]. Given these circumstances, the big issue is the distorted interpretation of fisheries governance resulting from the fact that traditional public fisheries management has been replaced by either more diffuse processes or others that are more strongly linked to the market, to large transnational companies and strong economic lobbies, with the more social aspects being somewhat sidelined. In short, fisheries management is now more flexible and "free", but the guarantees for safeguarding socio-economic and environmental rights have been excessively minimized, with accountability being more and more diffusely spread, and producer participation diluted in a wide and complex spectrum of social actors. There are, naturally, some specific structures and game rules (fisheries governance ${ }^{10}$ ). Nevertheless, greater effectiveness, capacity and legitimacy in the implementation of the decisions that affect both the sector and, especially, those whose livelihoods depend on it (fisheries governability), still remain to be achieved. The question is whether the latter of the two will be achieved or not on the basis of the "mercantilist" governance that is prevailing [40] and through a diffuse system of responsibilities in which the weakest social actors perceive participation more as rhetoric than a tangible reality.

\section{Concluding remarks}

The emergence of management formulae that seek greater social participation as part of the devolution process is resulting in a widening of the spectrum of social actors. One indicator that illustrates this is the emergence of the gender perspective, which has allowed a social group not traditionally taken into consideration in fisheries management to gain prominence. For this reason, it would be necessary to redefine the game rules not only because of the effect that the increase in the number of participants is having, but also because of the complexity that is inherent in the existence of a network of interactions between traditional and emerging actors who do not always share common interests.

Co-management can be understood to be a focus rather than a number of strictly technical solutions [41] that fits in with the new interactive governance approaches that are required to cater for the complex biological, socioeconomic, territorial, political and cultural relationships that in one way or another both shape and are shaped by

\footnotetext{
${ }^{10} \mathrm{An}$ analysis of fisheries governance and political institutions can be found in [39].
}

the fisheries chain when this is seen in a complex way [42]. It is, therefore, a perspective that is in keeping with the new concept of sustainability as it appears in the Code of Conduct for Responsible Fishing (FAO, 1995) and which subsequently has been expressed in ethical terms in the fisheries domain [43].

The paradigm of governance could in metaphorical terms be interpreted as a kind of matryoshka or "nested doll principle" "11; that is, a focus that, perhaps not always intentionally, both assumes and subsumes preceding management formulae in an attempt to construct a broader concept capable of taking on board the ever more complex participatory process. It could be said that the devolution approach and subsequent approaches relating to comanagement and, most recently, to governance/governability, serve to swell the ranks of management prescriptions, which have been progressively growing, and which, despite advocating self-regulation, shared management, social dialogue and the preservation of the environment, run the risk of being discourse rather than real political interventional praxis for the fisheries crisis [41].

\section{References}

[1] Crean K, Symes D, editors. Fisheries management in crisis. Oxford: Fishing News Books/Blackwell Science; 1996.

[2] European Commission. Dissemination of the results of biological studies 1997-20 $\equiv$ Brussels: European Comisión/Fisheries and Maritime Affair $\overline{\bar{F}}$ ectorate General; 2004

[3] European Commission. Synopsis of selected R \& D projects in the field of fisheries and aquaculture. Agriculture and Fisheries including agro-industry, food technology, forestry, aquaculture and rural development. FAIR 1994-98. EUR 18949 EN. Luxembourg: Fisheries Directorate-General; 2001.

[4] Gray T, Hatchard J. The 2002 reform of the Common Fisheries Policy's system of governance-rhetoric or reality? Marine Policy 2003;27(6):545-54.

[5] Florido D. Un siglo de política e instituciones pesqueras en Andalucía. Sevilla: Junta de Andalucía/Fundación Blas Infante; 2002.

[6] Apostle RA, et al. Community, state, and market on the north Atlantic rim. Challenges to modernity in the fisheries. Toronto: University of Toronto Press; 1998.

[7] Symes D, Phillipson J. Co-governance in EU fisheries: the complexity and diversity of fishermen's organisations in Denmark, Spain and UK. In: Kooiman J, et al., editors. Creative governance. Opportunities for fisheries in Europe. Aldershot: Ashgate; 1999.

[8] Van Hoof L, Hoefnagel E, van der Schans JW, Raakjær Nielsen J, Christensen AS, Sverdrup-Jensen S, et al. Sharing responsibilities in fisheries management. Final report. The Hague: LEI; 2005.

[9] Mulekon LV. An institutional development process in community based coastal resource management: building the capacity and opportunity for community based co-management in a small-scale fisheries community. Ocean and Coastal Management 1999:42:439-56.

[10] Wilson DC, Nielsen JR, Dengbol P, editors. The fisheries comanagement experience: accomplishments, challenges and prospects. Boston: Kluwer Academic Publishers; 2003.

\footnotetext{
${ }^{11}$ The metaphorical use of Russian matryoshkas denotes a recognizable relationship of "similar object-within-similar object" which could be applied to the construction of social and political formulations.
} 
[11] McGoodwin JR. Crisis in the world's fisheries: people, problems, and policies. Stanford, CA: Stanford University Press; 1990. p. 235.

[12] Noble BF. Institutional criteria for co-management. Marine Policy 2000;24:69-77.

[13] Sen S, Nielsen JR. Fisheries co-management: a comparative analysis. Marine Policy 1996;20(5):405-18.

[14] Nielsen JR, et al. Fisheries co-management-an institutional innovation? Lessons from South East Asia and Southern Africa. Marine Policy 2004;28:151-60.

[15] Jentoft S. Fisheries co-management: delegating government responsibility to fishermen's organisations. Marine Policy 1989;13(2):137-54.

[16] Pinkerton E, editor. Co-operative management of local fisheries. New directions for improved management and community development. Vancouver: British Columbia Press; 1989.

[17] Jentoft S, McCay BJ, Wilson DC. Social theory and fisheries comanagement. Marine Policy 1998;22(4/5):423-36.

[18] Mikalsen KH, Jentoft S. From users groups to stake holders? The public interest in fisheries management. Marine Policy 2001;25:281-92.

[19] McCay BJ, Jentoft S. Market or community failure? Critical perspectives on common property research. Human Organization 1998;57(1):21-39.

[20] Jentoft S. The Community: a missing link of fisheries management. Marine Policy 2000;24:53-9.

[21] Jentoft S. Fisheries co-management as empowerment. Marine Policy 2005;29:1-7.

[22] Pálsson G. Technology, practical knowledge and ecological expertise. In: Montes del Castillo Á, editor. Antropología de la pesca. Debates en el Mediterráneo. Universidad de Murcia, 1999.

[23] Neis B, et al. An interdisciplinary method for collecting and integrating fishers' ecological knowledge into resource management. In: Newell D, Ommer RE, editors. Fishing places, fishing people: traditions and issues in Canadian small-scale fisheries. Toronto: University of Toronto Press; 1999. p. 217-38.

[24] Stoker G. Governance as theory: five propositions. International Social Sciences Journal 1998;155:17-28.

[25] Kooiman J. Social-political governance: overview, reflections and design. Public Management Review 1999;1:67-92.

[26] Rosenau J, Czempiel EO, editors. Governance without government: order and change in world politics. Cambridge: Cambridge University Press; 1992.

[27] Rhodes RAW. The new governance: governing without government. Political Studies 1996;44(4):652-67.
[28] Vallès JM. Ciencia política. Una introducción. Barcelona: Ariel; 2000.

[29] Cicin-Sain B. Essay: a national ocean governance strategy for the United States is needed now. Coastal Management 1994;22:171-6.

[30] Kimball LA. International ocean governance: using international law and organizations to manage marine resources sustainably. Gland, Switzerland/Cambridge, UK: IUCN; 2001.

[31] Hinds L. Oceans governance and the implementation gap. Marine Policy 2003;27(4):349-56.

[32] Vallega A. Ocean governance in post-modern society - a geographical perspective. Marine Policy 2001;25(6):399-414.

[33] Lisbon Principles. In: Proceedings of the conference ecological economics and sustainable governance of the oceans, Lisbon, Portugal, 1997, 〈http://www.ids.org.au/ cnevill/marineLisbonPrinciples.htm >.

[34] Costanza R, et al. Principles for sustainable governance of the oceans. Science 1998;281:198-9.

[35] Mann Borgese E. The oceanic circle: governing the seas as a global resource. Tokyo/New York/Paris: United Nations University Press; 1998.

[36] Mann Borgese E, Bailet F. Ocean governance: legal, institutional and implementation considerations. A report prepared for the ship and ocean foundation of Japan. Halifax, Canada: Dalhousie UniversityInternational Ocean Institute; 2001.

[37] Gray TS. Theorising about participatory fisheries governance. In: Gray TS, editor. Participation in fisheries governance. Dordrecht, The Netherlands: Springer; 2005. p. 1-25.

[38] Cruz CN. Gobernabilidad y 'governance' democráticas: el confuso y no siempre evidente vínculo conceptual e institucional. Desarrollo humano e institucional en América Latina, 2001. p. 23. 〈http:// www.iigov.org/dhial $/ ? \mathrm{p}=23 \_05>$.

[39] Suárez de Vivero JL, Rodríguez Mateos JC, Florido del Corral D. Internacional institutions. In: Kooiman $\mathbf{J}$ et al., editors. Fish for life. Interactive governance for fisheries. Amsterdam: Amsterdam University Press, MARE publication series, No. 3; 2005. p. 197-216.

[40] Rodríguez Mateos JC. Justicia social y estructuras de poder en la gobernanza de la pesca. Jaina en línea 2002;13(1):17-23 〈http:// etzna.uacam.mx/epomex/pdf/jaina13-1.pdf $>$.

[41] Jentoft S. Beyond fisheries management: the Phronetic dimension. Marine Policy 2005;30:671-80.

[42] Kooiman J, et al., editors. Fish for life. Interactive governance for fisheries. Amsterdam: Amsterdam University Press; 2005.

[43] FAO. Ethical issues in fisheries. FAO ethics series, 4. Rome: Food and Agriculture Organization of the United Nations; 2005. 